
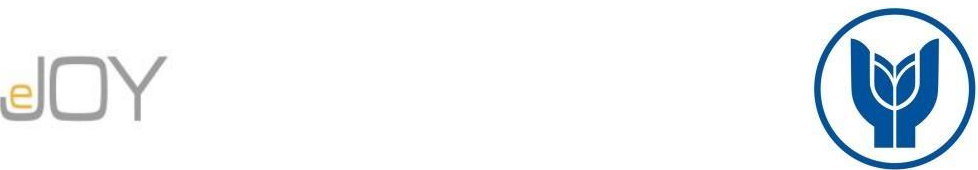

Sağlam, M. C., Kömürcü, S. / Journal of Yasar University, 2021, 16/63, 1355-1372

\title{
Bisiklet Etkinliği Katılımcılarının Motivasyonları ve İlgilenimleri: İzmir İli Üzerine Bir Çalışma
}

\section{Cycling Event Participants' Motivations and Involvement: A Research on İzmir}

\author{
Mehmet Cem SAĞLAM, Anadolu Üniversitesi, Türkiye, saglamcm@gmail.com \\ Orcid No: 0000-0003-1885-1279
}

Simge KÖMÜRCÜ, İzmir Kâtip Çelebi Üniversitesi, Türkiye, simge.komurcu@ikcu.edu.tr

Orcid No: 0000-0002-9094-3023

\begin{abstract}
Öz: Bisiklet etkinlikleri bisiklet turizmi kapsamında yapılan, katılımcllarına bir gruba üye olmak, farklı destinasyonlarl ziyaret etmek ve sosyalleşmek gibi deneyimler sunan, yarım gün veya tam gün olabildiği gibi konaklamalı tur organizasyonları ile de gerçekleştirilebilen faaliyetlerdir. Bisiklet etkinliklerine katılan bireylerin motivasyonlarının ve sürekli ilgilenim düzeylerinin tespit edilmesi, organizasyonların iyi bir şekilde planlanmasına ve yönetilmesine olanak sağlayacaktır. Bu kapsamda bu çalışmanın amacl, bisiklet etkinliklerine katılan bireylerin motivasyonlarının belirlenmesi, sürekli ilgilenim düzeylerinin ölçülmesi ve bu iki kavram arasındaki ilişkinin irdelenmesidir. Amaçlı örnekleme yöntemi kullanılan araştırmada 451 bisikletçiye ulaşılmıştır. Veriler 2019 yılı Aralık ayı ve 2020 yılı Ocak-Şubat-Mart aylarında İmir'de bisiklet gruplarının ve diğer organizatörlerin düzenlendiği bisiklet etkinliklerine katılan bireylerin oluşturduğu gruplara uygulanan anketlerden elde edilmiştir. Anket verileri SPSS (Statical Packages for Social Sciences) programı ile analiz edilmiştir. Çalışma kapsamında elde edilen en önemli bulgu, "Meydan Okuma” motivasyon boyutunun bağımlı değişkenler olarak nitelendirilen sürekli ilgilenim faktörlerinin tamamını etkilediği bulgusudur.
\end{abstract}

Anahtar Kelimeler: Etkinlik, Bisiklet Etkinlikleri, Motivasyon, Sürekli İlgilenim, İmir

JEL Sinıflandırması: L83, G14, Z32

Abstract: Cycling events are activities that are carried out within the scope of bicycle tourism, offering participants experiences such as being a member of group, visiting different destinations and socializing and can be carried out with half-day or full-day tour organizations as well as with accommodation tour organizations. Determining the motivation and enduring involvement of the individuals participating in cycling events will enable organizations to be well planned and managed. In this context, the aim of this study is determining cycling event participants' motivations, measure level of their enduring involvement and examining the relationship between these two concepts. In the study, in which purposeful sampling method was used, 451 cyclists were reached. The data were obtained from the surveys applied to groups of individuals who participated in cycling activities organized by bicycle groups and other organizers in Izmir In December 2019 and in January-February-March 2020. Questionnaire data were analyzed with SPSS (Statistical Packages for Social Sciences) program. The most important finding obtained within the scope of the study is the "Personal Challenge" as the motivation dimension affects all the enduring involvement factors, which are defined as dependent variables.

Keywords: Event, Cycling Events, Motivation, Enduring Involvement, İzmir

JEL Classification: L83, G14, Z32

\section{Giriş}

Bisiklet sürmek, ücretsiz, eğlenceli ve faydalı bir boş zaman faaliyetidir. Bisiklet etkinlikleri ise yediden yetmişe ilgi duyan herkesin katılabileceği aktivitelerdir. Toplumu oluşturan kesimlerin büyük bir çoğunluğunun turizm kapsamına girecek hizmetlerden yararlandığı göz önüne alındığında (Yılmaz ve Güler 2017, 18) bisiklet etkinlikleri de turizm kapsamında pek çok turiste hitap etmektedir. Bisiklet etkinliklerinin bireysel ve çevresel pek çok faydası Makale Geçmiși / Article History 
bulunmaktadır (Özdemir 2015, 321). Bisiklet etkinliklerinin bireylere ve destinasyonlara faydalarının yanı sıra ekonomik değer yaratma ve yeni iş kolları oluşturma gibi avantajları da bulunmaktadır (Weigand 2008, 9). Son y1llarda destinasyonlar, turizm teklifleri geliştirmek ve destinasyonlar arası rekabette söz sahibi olabilmek amacıyla bisiklet etkinliklerinden, dolayısıyla bisiklet turizminden faydalanmak istemektedirler (Gazzola ve diğerleri 2018, 1).

Destinasyonların bisiklet turizmi pazarından pay alabilmeleri için hedef pazarlarını çok iyi tanımaları gerekmektedir. Bu kapsamda bisiklet etkinliklerine katılan bireylerin davranışlarını açıklayan en önemli unsurlardan biri kişilerin motivasyonlarının belirlenmesi ve önceliklendirilmesidir (Crompton ve Mckay 1997, 426). Motivasyon, turistlerin seyahat davranışlarının açıklanmasında etkili olan pek çok değişkenden (algılanan hedef, kültürel koşullanma, öğrenme vb.) yalnızca biri olmasına rağmen, davranışların arkasındaki temel itici güç olması sebebiyle kritik bir değişken olarak kabul edilmektedir (Fodness 1994, 555). Ayrıca motivasyon unsurlarının belirlenmesi, turistlerle olan iletişimin güçlenmesi ve turistik ürünlerin tüketiminin artırılması için önemli bir adım olarak görülmektedir (Simkova ve Holzner 2014, $660)$.

Yapılan araştırmalar, belirli bir etkinliğe katılımı etkileyebilecek motivasyon dışı faktörlerden bir diğerinin de sürekli ilgilenim olduğunu göstermektedir (Thapa ve diğerleri 2004, 208). Etkinliklere katılan bireyler bu faaliyetlere yoğun ilgilenim gösterdiklerinde süreklilik ve bağlılık kazanarak etkinlikleri hayatlarının bir parçası hâline getirmektedirler. Bu tür etkinliklere katılım sağlayan bireyler, etkinliklere karşı basit düzeyde ilgilenim göstermekle kalmazlar, aynı zamanda hayatlarının uzun bir döneminde düzenli bir şekilde ilgilenim gösterirler (Gürbüz ve diğerleri 2018, 257).

Bisiklet turizmi kapsamında Türkiye'de yapılan motivasyon çalışmalarının sınırlı sayıda olduğu ve bu etkinliklere katılan bireylerin sürekli ilgilenim düzeylerinin ölçülmesine yönelik alanyazında herhangi bir çalışmanın bulunmadığı görülmektedir. Bu kapsamda İzmir'de bisiklet etkinliklerine katılan bireylere uygulanan bu araştırmanın amacı, etkinliklere katılan bireylerin demografik özelliklerinin belirlenmesi, bireyleri etkinliklere yönelten motivasyon unsurlarının ve ilgilenim düzeylerinin saptanması ve motivasyon-ilgilenim boyutları arasındaki ilişkinin irdelenmesidir.

\section{Kuramsal Çerçeve}

Büyükşehirlerde yaşayan insanlar yoğun iş yükü, sıkıcı ve sıradan hayatlar ve stres gibi faktörlerden olumsuz etkilenmektedirler. Bu olumsuzlukların yanı sıra teknolojinin gelişmesi ve beraberinde getirdiği küreselleşme olgusu, ulaşım imkânlarının artması, çalışma saatlerinde 
yapılan iyileştirmeler ve kişi başına düşen milli gelirdeki artışlar insanları boş zaman faaliyetlerine itmekte ve boş zaman faaliyetleri kapsamında yapılan etkinlikleri hayatlarının bir parçası hâline getirmektedir (Can 2015, 2). Etkinlik kavramı, özel günleri ve/veya planlanmış organizasyonları (sunumlar, ritüeller, performanslar, spor etkinlikleri, ürün lansmanları vb.) tanımlamak için kullanılmaktadır. Uysal ve diğerleri (1993, 5) etkinlikleri "ziyaretçilerin başarılı bir şekilde ağırlanmasını sağlayan, bir bölgenin kültürel kaynakları” şeklinde tanımlamaktadır. Jago ve Shaw $(1998,29)$ ise etkinlikleri "tüketiciye günlük deneyimin ötesinde bir boş zaman ve sosyal firsatlar sunan, bir süreliğine veya nadiren gerçekleştirilen sınırlı süreli faaliyetler" şeklinde ifade etmektedir.

Sürekli gelişen turizm endüstrisinde yıllar içerisinde değişen seyahat şekilleri ve farklılaşan turist motivasyonlarının etkisiyle pek çok alternatif turizm türü ortaya çıkmıştır (Sarıbaş ve diğerleri 2020, 50). Etkinlik turizmi de bu turizm türleri sınıflandırmaları içerisinde yer almaktadır. Yöneticiler ve profesyoneller tarafindan destinasyonlar arası rekabette avantaj elde etmek, ekonomik getiri sağlamak ve olumlu bir imaj kazanmak gibi nedenlerle yeni ve özgün etkinlikler geliştirilmektedir. Bisiklet etkinlikleri de bu etkinlikler arasında yer almaktadır. Bisiklet etkinlikleri "genellikle trafik akışının olmadığı güvenli yollarda / patikalarda, kısmen veya tamamen organize edilmiş, günün belli kısımlarında / günübirlik veya kamp kurmalı olarak yapılan etkinlikler” şeklinde ifade edilmektedir (Ardahan ve Mert 2014, 411).

Etkinliklerin destinasyonlara sağladığı faydaları artırmak için etkinlik yöneticilerine etkinliklere katılan bireylerin motivasyonları hakkında doğru bilgi vermek gerekmektedir (Kim ve diğerleri 2002, 127). Etkinlik katılımına yönelik motivasyonları analiz etmek, etkinlik yöneticilerine pazarlama çalışmalarında fayda sağlarken, yöneticilere her pazarın güçlü yanlarını ve imkânlarını tanımlama firsatı sunacaktır (Lee ve diğerleri 2004, 69). Ek olarak motivasyon sayesinde turizm pazarları bölümlere ayrılabilecek ve kıt turizm kaynakları daha verimli şekilde kullanılabilecektir (Uysal ve diğerleri 2008, 413).

Motivasyon, turist davranışlarını açıklamada kullanılan en temel unsurlardan biridir (Kim ve diğerleri 1996, 102). Motivasyon kavramı "insanların belirli şekillerde davranmalarına neden olan faktörler kümesi” olarak tanımlanmaktadır (Schwartz 2006, 15). Turist motivasyonu ise "genel anlamda seyahat etme eğilimini etkileyen ihtiyaç ve arzuların birleşimi”" olarak kabul edilmektedir (O’Leary ve Deegan 2005, 247). Tüm bu tanımlardan yola çıkıldığında temel motivasyon teorisi, bireylerin zihinlerinde ve vücutlarında rahatsızlık verecek düzeyde gerilim oluşturan ihtiyaçlar, istekler ve amaçlar gibi psikolojik faktörlere bağlı bir süreç olarak ele alınmaktadır. Gerilim ile sonuçlanan gizli ihtiyaçların varlı̆̆ı, gerilimi azaltacak faaliyetlerin 
gerçekleştirilmesini, dolayısıyla ihtiyaçların karşılanmasını gerektirecektir (Fodness 1994, $555)$.

Turizm araştırmacıları uzun yıllardır turistlerin seyahat kararlarını ve tüketim davranışlarını daha iyi anlamak ve tahmin etmek için seyahat, motivasyon ve turizm destinasyonlarına yönelik tutumları incelemektedirler. Bu bağlamda araştırmacılar turist davranışını açıklamak için bir dizi motivasyon kuramı geliştirmiş ve uygulamışlardır (Uysal ve diğerleri 2008, 413).

Motivasyon konusundaki en temel yaklaşımlardan biri Maslow' un geliştirdiği ihtiyaçlar hiyerarşisi teorisidir. Maslow (1970)'a göre insan ihtiyaçlarını karşıladığında mevcut ihtiyacın yerini üst sıradaki başka bir ihtiyaç almaktadır. Maslow (1970), insan ihtiyaçlarını beş temel kategoride sınıflandırmıştır. Bu ihtiyaçlar fizyolojik ihtiyaçlar, güvenlik ihtiyacı, ait olma ve sevgi ihtiyacı, saygınlık ihtiyacı ve kendini gerçekleştirme ihtiyacıdır. Pearce, Maslow' un İhtiyaçlar Hiyerarşisinden yararlanarak Seyahat Kariyer Merdiveni (TCL) kuramını 1988 yılında geliştirmiştir. Bu kavramsal çerçevenin altında yatan temel fikir, bir bireyin seyahat motivasyonunun seyahat deneyimi ile değiştiğidir (Huang ve Hsu 2009, 288). Teoriye göre, en temel düzeydeki ihtiyaç, rahatlama ihtiyacı olarak belirtilmektedir. Bu ihtiyacı uyarılma ihtiyacı, ilişki ihtiyacı, özsaygı ve gelişim ihtiyaçları ve kendini gerçekleştirme ihtiyaçları takip etmektedir (Kim ve diğerleri 1996, 103).

Motivasyon ile ilişkili pek çok kuram olmasına rağmen en çok kabul gören ve araştırmacılar tarafından çalışılan kuram Dann (1977) ve Crompton (1979) tarafından geliştirilen itme ve çekme motivasyon faktörleri kuramıdır. İtme ve çekme motivasyon faktörleri kuramının turizm yazınında önemli olmasının nedeni, bu kuramın turistlerin ihtiyaçlarını belirleyerek onları en iyi şekilde memnun edecek hizmetleri veya ürünleri belirleme firsatı sunmasıdır (Francis 2003, 35). Diğer bir kuram olan alosentrizm ve psikosentrizm kuramı Stanley Plog tarafindan psikolojik yaklaşımla yapılandırılmıştır (Bayrakçı 2014, 17). Plog’a göre allosentrikler, bağımsız gezmeyi tercih ederken, tam zıttı olan psikosentrikler bilinen yerlere grupla seyahat etmeyi tercih etmektedir (Uysal ve diğerleri 2008, 417). Motivasyon kavramına sosyopsikolojik açıdan yaklaşan Iso-Ahola (1982) ise kaçış ve arayış kuramını geliştirmiştir. Bu modele göre, turistlerin davranışlarını etkileyen iki motivasyonel güç vardır. Bunlardan ilki kaçış diğeri ise arayıştır (Park ve diğerleri 2008, 162).

İlgilenim aynı zamanda yüksek motivasyon hâli olduğundan, bireyin daha önceden katılmış olduğu faaliyetlere tekrar katılım sağlama davranışını ortaya koymaktadır. Birçok insan günlük programlarını ve hatta yaşam tarzını etkinliklere uyum sağlamak ve etkinliklere büyük oranda dâhil olmak için ayarlamaktadır (Havitz ve Howard 1995, 257). Sürekli ilgilenim kavramının bisiklet turizmi ve bisiklet etkinlikleri gibi niş turizm pazarlarına uygulanması gerekmektedir. 
Çünkü katılım temelli faaliyetler, yüksek düzeyde sürekli ilgilenim davranışları barındırmaktadırlar (Ritchie ve diğerleri 2010, 412). Venkatraman (1989, 230) sürekli ilgilenimi "bir tüketicinin ürün hakkındaki bilgisinden veya deneyiminden elde ettiği keyif ya da zevk duygusuyla motive olmak suretiyle o ürüne karşı devam eden ilgisi” olarak tanımlamaktadır. İlgilenimin yapısı boş zaman, rekreasyon ve turizm araştırmalarında yaygın olarak incelenmektedir (Kouthouris 2009, 5). İlgilenim: "bir etkinliğe, rekreatif bir aktiviteye veya ilgili bir ürüne karşı gözlemlenemeyen bir motivasyon, uyarılma veya ilgi durumu” olarak tanımlanmaktadır (Havitz ve Dimanche 1997, 246). Bu tanımdan hareketle ilgilenim ile belirli bir etkinliğe katılım için gerekli olan motiveler arasında pozitif yönlü bir ilişsi olduğu söylenebilmektedir (Akkoç 2015, 49). Alanyazınında bireylerin motivasyonları ve ilgilenimleri arasındaki ilişkiyi ortaya koyan araştırmalar bulunmaktadır. Motivasyon ve ilgilenim arasındaki ilişkiye yönelik ilk çalışma 1997 yılında Kimberly M. Rey tarafından yapılmıştır. Araştırmacı bireyleri egzersiz yapmaya motive eden unsurlar ve birey davranışları arasındaki ilişkiyi incelerken sürekli ilgilenim düzeylerini ara değişken olarak kullanmıştır. Araştırma 531 üniversite öğrencisine uygulanmıştır. Çalışmada 38 ifadeli tutum ölçeği kullanılmıştır. Araştırma sonuçlarına göre bireyleri egzersiz yapmaya motive eden unsurlardan "kilo yönetimi, sosyalleşme, stres azaltma, sağlık ve zindelik” güdüleri ile egzersiz yapan bireyler, diğer bireylere göre daha yüksek bir ilgilenim sergilemektedirler. Diğer bir deyişle, bu motivasyon unsurlarına sahip bireylerin sürekli katılıma daha yatkın oldukları saptanmıştır (Rey 1997'den aktaran Akkoç 2015, 49).

Kyle ve diğerleri (2005) ve Kyle ve diğerleri (2006) motivasyon ve ilgilenim arasındaki ilişkiyi belirlemek amacıyla 424 katılımcı ile çalışmalar yapmışlardır. Yapılan çalışmalarda ABD’deki Güneydoğu Ulusal Ormanı'ndaki üç ayrı kamp alanında kamp yapan kişilerden veriler toplanmıştır. 2005 yılında yapılan çalışmada motivasyon ve ilgilenim arasındaki ilişki incelenirken, 2006 yılında ise motivasyon ve sürekli ilgilenim arasındaki ilişki incelenmiştir. Araştırmalar kapsamında kullanılan ilgilenim ölçekleri Kyle ve diğerlerine (2004) ait beş boyut ve on beş ifadeden oluşan ölçeklerdir. Motivasyon ölçekleri ise Manfredo ve diğerlerine (1996) ait olan ve on beş ifadeden oluşan ölçeklerdir. Araştırma bulgularına göre, bireyleri motive eden unsurların ilgilenimin de önemli bir parçası olduğu ve motivasyon boyutlarının ilgilenim boyutlarının olumlu birer yönlendiricisi olduğu saptanmıştır.

Kim (2008) tarafından yapılan bir başka çalışmada ise, yurt içi ve yurt dışında en popüler destinasyonları ziyaret eden Kuzey Karolina'daki üniversite öğrencileri ve öğrencilerin sahip oldukları sadakat, memnuniyet, motivasyon ve ilgilenim düzeylerinin arasındaki ilişkiyi incelenmiş, elde edilen bulgular Yapısal Eşitlik Modeli kullanılarak çözümlenmiştir. Araştırma 
kapsamında 56 motivasyon ifadesi ve 9 çift ilgilenim ifadesinin yer aldığı anket 411 üniversite öğrencine uygulanmıştır. Araştırma sonucunda üniversite öğrencilerinin sahip oldukları tatil motivasyonlarının öğrencilerin ilgilenim düzeylerini pozitif yönde etkilediği bulgusuna ulaşılmıştır.

Chang ve Huang (2012), yamaç paraşütü katılımcılarının sürekli ilgilenim düzeylerini belirlemeye yönelik bir araştırma gerçekleştirmiştir. Araştırmada Beard ve Ragheb (1983)'in çalışmasından 17 adet motivasyon ifadesi ve Zaichkowsky (1994) 'nin çalışmasından 12 adet ilgilenim ifadesi kullanılmıştır. Anketler Tayvan'daki tüm yamaç paraşütü derneklerine ve kulüplerine postalanmış ve toplam 193 geçerli anket toplanmıştır. Çalışmada korelasyon ve çoklu regresyon analizleri kullanılarak motivasyon ve sürekli ilgilenim arasındaki ilişki açıklanmıştır. Çalışmada yamaç paraşütü faaliyetlerine katılan bireylerin motivasyon ve ilgilenimleri arasında güçlü ve pozitif yönlü bir ilişki olduğu saptanmıştır.

\section{Yöntem}

Çalışmada bisiklet etkinliklerine katılan bireylerin motivasyonlarını ve sürekli ilgilenim düzeylerini belirlemek ve bu bireylerin demografik bilgilerine ulaşabilmek amaciyla nicel araştırma yöntemlerinden yararlanılmıştır. Hipotez test etmek veya hazırlanan araştırma sorularına cevaplar bulmak amacıyla evreni temsil eden bir örneklemden alınan sayısal verilerin analiz edilmesini sağlayan yöntem, nicel araştırma yöntemidir (Başol 2008, 7). Araştırma kapsamında İzmir'de bisiklet etkinliklerine katılan bireylerin tamamına ulaşmanın zaman ve maliyet açısından zorlukları olması nedeniyle evreni temsil eden bir örneklem seçilmiştir. Seçilen örneklemden sayısal veriler elde etmek amacıyla da anket formu kullanılmıştır.

Araştırmada, Ritchie ve diğerlerinin 2010 yılında yaptıkları "Understanding the Motivation and Travel Behavior of Cycle Tourists Using Involvement Profiles" adlı çalışmada geliştirilen ölçeklerden yararlanılmıştır. İzmir ilinde gerçekleştirilen bisiklet etkinliklerine katılan bireylere uygulanan ölçek üç bölümden oluşmaktadır. Ölçeğin birinci bölümünü bisiklet etkinliklerine katılan bireylerin motivasyonlarını belirlemeye yönelik oluşturulan on yedi soru oluşturmaktadır. Bu sorular Ritchie ve diğerleri (2010) tarafından Ritchie (1998) ve Ritchie'nin (2000) yapmış olduğu araştırmalardan faydalanılarak hazırlanmış ve Avustralya'da bisiklet etkinliklerine katılan bireylere uygulanmıştır. Sürekli ilgilenim ölçeği ise Ritchie ve diğerleri (2010) tarafından McIntyre'nin (1989) yaptığı araştırmalardan faydalanılarak hazırlanmıştır. Oluşturulan ölçek Türkçeleştirilerek İzmir ilinde gerçekleştirilen bisiklet etkinliklerine katılan bireylere uygulanmıştır. Ölçeğin Türkçeleştirme çalışması yapılırken 3 farklı araştırmacıdan destek alınmıştır. Ölçek öncelikle İngilizceden Türkçeye çevrilmiş, ifade bozuklukları kontrol 
edilmiştir. Araştırmacılardan alınan veriler sonrası son hâline getirilen ölçek uygulamaya hazır hâle getirilmiştir. Anketin üçüncü bölümünde ise katılımcıların demografik özelliklerine ve diğer açıklayıcı ifadelere yer verilmektedir.

Veriler 2019 yılı Aralık ayı ve 2020 yılı Ocak-Şubat-Mart aylarında İzmir'de bisiklet gruplarının ve diğer organizatörlerin düzenlendiği bisiklet etkinliklerine katılan bireylerin oluşturduğu gruplara uygulanan anketlerden elde edilmiştir. Etkinliklere katılan bireylere toplamda 507 adet anket dağıtılmıştır. Dağıtılan bu anketlerden 56 tanesi eksik ve hatalı olması nedeniyle değerlendirmeden çıkarılmış ve geriye kalan 451 adet anket ile analizler gerçekleştirilmiştir. Yapılan bu çalışmada örnekleme yöntemi olarak amaçlı örnekleme yöntemi seçilmiştir. Amaçlı örnekleme, bir katılımcının nitelikleri nedeniyle kasıtlı seçim tekniğidir (Etikan ve diğerleri 2016). Araştırmada elde edilmek istenen bulgulara yönelik geliştirilen araştırma soruları aşağıda sıralanmaktadır;

1. İzmir'de düzenlenen bisiklet etkinliklerine katılan bireylerin demografik özellikleri nelerdir?

2. İzmir'de düzenlenen bisiklet etkinliklerine katılan bireylerin bu etkinliklere katılımlarını etkileyen motivasyon unsurları nelerdir?

3. İzmir'de düzenlenen bisiklet etkinliklerine katılan bireylerin sürekli ilgilenimleri ne düzeydedir?

4. İzmir'de düzenlenen bisiklet etkinliklerine katılan bireylerin motivasyonları ve sürekli ilgilenim düzeyleri, katılımcıların demografik özelliklerine göre farklılık gösterir mi?

5. İzmir'de düzenlenen bisiklet etkinliklerine katılan bireylerin motivasyonları, sürekli ilgilenim düzeylerine ne derece etki etmektedir?

Elde edilen veriler SPSS 22 istatistik paket programı ile analiz edilmiştir. Verilerin analiz edilmesinde öncelikle normal dağılım analizlerinden yararlanılmıştır. Verilerin normal dă̆glımı tespit edildikten sonra sirasıyla frekans analizi, güvenilirlik analizi, t-testi, anova testleri, korelasyon analizi ve regresyon analizleri yapılmış ve yorumlanmıştır.

\section{Bulgular}

Çalışma kapsamında hazırlanan araştırma sorularından birincisine yönelik elde edilen bulgular Tablo 1'de sunulmuştur. Bu kapsamda tabloda bisiklet etkinliklerine katılan bireylerin yaşları, cinsiyetleri, eğitim düzeyleri, deneyim düzeyleri, deneyim süreleri ve bisiklete binme sıkl1klarına ait bilgiler verilmektedir. 
Tablo 1. Katılımcıların Demografik Özelliklerine İlişkin Frekans Analizi

\begin{tabular}{|c|c|c|c|}
\hline $\begin{array}{c}\text { Demografik } \\
\text { Özellik }\end{array}$ & Kategori & Frekans & $\begin{array}{c}\text { Yüzde } \\
(\%)\end{array}$ \\
\hline \multirow{6}{*}{ Yaş } & $15-24$ & 32 & 7.1 \\
\hline & $25-34$ & 111 & 24.6 \\
\hline & $35-44$ & 143 & 31.7 \\
\hline & $45-54$ & 111 & 24.6 \\
\hline & $55-64$ & 47 & 10.4 \\
\hline & $65+$ & 7 & 1.6 \\
\hline \multirow[t]{2}{*}{ Cinsiyet } & Kadın & 122 & 27.1 \\
\hline & Erkek & 329 & 72,9 \\
\hline \multirow{5}{*}{ Eğitim Düzeyi } & İlkokul & 3 & 0.7 \\
\hline & Ortaokul & 14 & 3.1 \\
\hline & Lise & 116 & 25.7 \\
\hline & Üniversite & 253 & 56.1 \\
\hline & Lisansüstü & 65 & 14.4 \\
\hline \multirow[t]{3}{*}{ Deneyim Düzeyi } & Başlangıç Düzeyi & 23 & 5.1 \\
\hline & Orta Düzey & 222 & 49.2 \\
\hline & Üst Düzey & 206 & 45.7 \\
\hline \multirow{6}{*}{ Deneyim Süresi } & Düzenli Bisiklet & 20 & 4.4 \\
\hline & Sürmüyorum & & \\
\hline & 5 Yildan Az & 36 & 8.0 \\
\hline & 1-5 Y1l Aras1 & 122 & 27.1 \\
\hline & 6-10 Y1l Aras1 & 111 & 24.6 \\
\hline & 11 Yil ve Üstü & 162 & 35.9 \\
\hline \multirow{6}{*}{$\begin{array}{c}\text { Bisiklete Binme } \\
\text { Sıklığ } 1\end{array}$} & Haftada 1 Defadan Az & 30 & 6.7 \\
\hline & Haftada 1 Defa & 36 & 8.0 \\
\hline & Haftada 1-3 Defa & 196 & 43.5 \\
\hline & Haftada 4-6 Defa & 87 & 19.3 \\
\hline & Her gün & 75 & 16.6 \\
\hline & Diğer & 27 & 6.0 \\
\hline
\end{tabular}

Tablo 1 incelendiğinde etkinliklere katılan bireylerin büyük çoğunluğunun 35-44 yaş aralığında (\%31.7) olduğu görülmektedir. Katılımcıların yalnızca 1.6's1 65 yaş ve üstünü temsil etmektedir. Katılımcıların büyük çoğunluğunun erkek bireylerden (\%72.9) oluştuğu tespit edilmiştir. Eğitim düzeyleri bakımından incelendiğinde katılımcıların eğitim düzeylerinin oldukça yüksek olduğu görülmektedir. Üniversitesi mezunu bireylerin (\%56.1) diğer düzeylere göre daha çoğunlukta olduğu tespit edilmiştir. Deneyim düzeyleri incelendiğinde ise katılımcılardan 23 kişi (\%5.1) hariç orta ve üst düzey deneyime sahip olduklarını belirtmiştir. Katılımcıların \%35.9’u 11 y1l ve üstü deneyim süresine sahip olduğunu belirtirken bu oran düzenli bisiklet kullanmayanlarda \%4.4'te kalmaktadır. Son olarak katılımcıların büyük çoğunluğunun haftada 1-3 defa bisiklete binmeyi tercih ettikleri saptanmıştır.

Bisiklet etkinliklerine katılan bireylere ait açıklayıcı istatistiklere yer verildikten sonra çalışmada yapısal geçerliliği test etmek amacıyla motivasyon ve sürekli ilgilenim ölçeklerine faktör analizi uygulanmıştır. Elde edilen sonuçlar Tablo 2'de sunulmuştur. 
Tablo 2. Motivasyon ve Sürekli İlgilenim İfadelerine Yönelik Faktör Analizleri Sonuçları

\begin{tabular}{|c|c|c|c|}
\hline Faktörler-Maddeler & $\begin{array}{l}\text { Faktör } \\
\text { Yükü }\end{array}$ & $\begin{array}{l}\text { Açıklanan } \\
\text { Varyans } \\
\text { Oranı }\end{array}$ & Güvenirlik \\
\hline \multicolumn{4}{|l|}{ Motivasyon İfadelerine Ait Faktör Analizi Sonuçları } \\
\hline Rahatlama-Kaçış & & 39,673 & 0,837 \\
\hline Huzur ve sükûnet için bisiklet etkinliklerine katılırım. & ,885 & & \\
\hline Rahatlamak için bisiklet etkinliklerine katılırım. & ,851 & & \\
\hline Monotonluktan kurtulmak için bisiklet etkinliklerine katılırım. & ,708 & & \\
\hline Yetkinlik & & 10,467 & 0,726 \\
\hline Bisiklet becerilerimi geliştirmek için bisiklet etkinliklerine katılırım. & ,776 & & \\
\hline Deneyim kazanmak için bisiklet etkinliklerine katılırım. & ,699 & & \\
\hline Fiziksel açıdan formda kalmak için bisiklet etkinliklerine katılırım. & ,692 & & \\
\hline Sosyalleşme & & 8,447 & 0,671 \\
\hline $\begin{array}{l}\text { Arkadaşlarımla / ailemle birlikte olmak için bisiklet etkinliklerine } \\
\text { katılırım. }\end{array}$ & ,797 & & \\
\hline Bilgi ve becerilerimi paylaşmak için bisiklet etkinliklerine katılırım. & ,681 & & \\
\hline Yeni insanlarla tanışmak için bisiklet etkinliklerine katılırım. & 643 & & \\
\hline Macera Deneyimi & & 7,330 & 0,793 \\
\hline Macera yaşamak için bisiklet etkinliklerine katılırım. & ,885 & & \\
\hline Heyecan yaşamak için bisiklet etkinliklerine katılırım. & ,769 & & \\
\hline Meydan Okuma & & 6,010 & 0,760 \\
\hline Bisiklet etkinliklerine katılırım çünkü bisiklete binmek etkileyicidir. & ,737 & & \\
\hline Kendime güvenimi geliştirmek için bisiklet etkinliklerine katılırım. & ,653 & & \\
\hline $\begin{array}{l}\text { Bu işi kendime yapabildiğimi göstermek için bisiklet etkinliklerine } \\
\text { katılırım. }\end{array}$ & 613 & & \\
\hline
\end{tabular}

\begin{tabular}{|c|c|c|c|}
\hline Faktörler-Maddeler & $\begin{array}{l}\text { Faktör } \\
\text { Yükü }\end{array}$ & $\begin{array}{l}\text { Açıklanan } \\
\text { Varyans } \\
\text { Oranı }\end{array}$ & Güvenirlik \\
\hline \multicolumn{4}{|l|}{ Sürekli İlgilenim İfadelerine Ait Faktör Analizi Sonuçları } \\
\hline Kişisel Zevk & & 46,773 & 0,822 \\
\hline Bisiklete binmek yaptığım en tatmin edici şeylerden biridir & ,861 & & \\
\hline Bisiklete binmek, yaptı̆̆ım en eğlenceli șeylerden biridir. & ,840 & & \\
\hline Bisiklete binmek benim için önemlidir. & 691 & & \\
\hline Sosyal Bağlanma & & 12,408 & 0,776 \\
\hline $\begin{array}{l}\text { Arkadaşlarımın çoğunun hayatında bir şekilde bisiklet binmeye yer } \\
\text { vardır. }\end{array}$ & 817 & & \\
\hline Hayatımın çoğunun bisiklet etrafında organize olduğunu görüyorum. & ,779 & & \\
\hline Bisiklet etkinliklerine beraber katıldı̆ıı insanları iyi tanırım & ,688 & & \\
\hline $\begin{array}{l}\text { Arkadaşlarımla bisikletler ve etkinlikler hakkında konuşmaktan } \\
\text { hoșlanırım }\end{array}$ &, 564 & & \\
\hline Kendini Iffade Etme & & 7,773 & 0,728 \\
\hline Bisiklet sürerken gerçekten kendim olabilirim & 801 & & \\
\hline Bisiklet, kim olduğum hakkında çok şey söylüyor &, 750 & & \\
\hline $\begin{array}{l}\text { Stres altındayken bisiklet etkinliklerine katılmak bana rahatlama } \\
\text { sunuyor }\end{array}$ & 602 & & \\
\hline
\end{tabular}

$(*): \mathrm{p}<0,05$

Araştırma kapsamında hazırlanan ikinci ve üçüncü sorulara cevap bulmak amacıyla yapılan faktör analizleri neticesinde İzmir'de bisiklet etkinliklerine katılan bireylerin motivasyonları sırasıyla "Rahatlama/Kaçış, Yetkinlik, Sosyalleşme, Macera Deneyimi ve Meydan Okuma" 
şeklinde iken sürekli ilgilenim düzeyleri önem sırasına göre "kişisel zevk, sosyal bağlanma ve kendini ifade etme" şeklinde saptanmıştır.

İzmir'de düzenlenen bisiklet etkinliklerine katılan bireylerin motivasyonları ve sürekli ilgilenim düzeyleri, katılımcıların demografik özelliklerine göre farklılık gösterip göstermediğini saptamak amaciyla korelasyon analizi, t-testi ve anova testlerinden yararlanılmıştır. Katılımcıların yaşları ile motivasyonları ve sürekli ilgilenimleri arasında anlamlı bir ilişki olup olmadığı Pearson korelasyon katsayısı aracılığıyla incelenmiştir. Pearson korelasyon katsayısı " $r$ " harfi ile gösterilmektedir. Bu katsayı -1 ile +1 arasında değișen değerler almaktadır (Sipahi ve diğerleri, 2008: 144). İlişki katsayısı olan "r" değeri 0-0,30 arasında çıkması zayıf, 0,30-0,70 arasında korelasyon orta, 0,70-1 arasında kuvvetli ilişki göstermektedir (Sipahi ve diğerleri 2008, 145). Yapılan analiz neticesinde motivasyon faktörlerinden "macera deneyimi" ve sürekli ilgilenim faktörlerinden "sosyal bağlanma ve kendini ifade etme" boyutları katılımcıların yaşlarıyla anlamlı bir ilişkiye sahiptir. Aralarındaki ilişski r değeri cinsinden incelendiğinde 3 boyutunda negatif yönlü ve zayıf bir ilişkiye sahip oldukları tespit edilmiştir.

Etkinliklere katılan bireylerin motivasyonları ve sürekli ilgilenim düzeyleri ile katılımcıların cinsiyetleri ve deneyim düzeyleri (gözlem sayıları arasındaki fark fazla olması sebebiyle bir grup analizden çıkartılmış ve t-testi yapılmasına karar verilmiştir) arasında farklılık olup olmadığı grup sayısının iki olması sebebiyle t-testi aracılığıyla saptanmış ve elde edilen bulgular Tablo 3'te verilmiştir.

Tablo 3. Motivasyon ve Sürekli İlgilenim Düzeylerinin Cinsiyet ve Deneyim Düzeyine Göre Farklılığ 1

\begin{tabular}{|c|c|c|c|c|c|c|}
\hline \multicolumn{2}{|c|}{ Cinsiyet } & $\mathrm{N}$ & Ortalama & SS & $\mathrm{T}$ & $\mathrm{P}$ \\
\hline \multicolumn{7}{|c|}{ Motivasyon Faktörlerine Illişkin Sonuçlar } \\
\hline Rahatlama/Kaçış & $\begin{array}{l}\text { Kadın } \\
\text { Erkek }\end{array}$ & $\begin{array}{l}122 \\
329 \\
\end{array}$ & $\begin{array}{l}4,647 \\
4,521\end{array}$ & $\begin{array}{l}0,564 \\
0,697\end{array}$ & 1,967 & 0,050 \\
\hline Yetkinlik & $\begin{array}{l}\text { Kadın } \\
\text { Erkek }\end{array}$ & $\begin{array}{l}122 \\
329 \\
\end{array}$ & $\begin{array}{l}4,388 \\
4,119\end{array}$ & $\begin{array}{l}0,674 \\
0,874 \\
\end{array}$ & 3,452 & $0,001^{*}$ \\
\hline Sosyalleşme & $\begin{array}{l}\text { Kadın } \\
\text { Erkek }\end{array}$ & $\begin{array}{l}122 \\
329 \\
\end{array}$ & $\begin{array}{l}3,754 \\
3,737 \\
\end{array}$ & $\begin{array}{l}0,917 \\
0,948\end{array}$ & 0,166 & 0,869 \\
\hline Macera Deneyimi & $\begin{array}{l}\text { Kadın } \\
\text { Erkek }\end{array}$ & $\begin{array}{l}122 \\
329 \\
\end{array}$ & $\begin{array}{l}3,491 \\
3,717\end{array}$ & $\begin{array}{l}1,144 \\
1,161\end{array}$ & $-1,839$ & 0,067 \\
\hline Meydan Okuma & $\begin{array}{l}\text { Kadın } \\
\text { Erkek }\end{array}$ & $\begin{array}{l}122 \\
329 \\
\end{array}$ & $\begin{array}{l}4,032 \\
3,695 \\
\end{array}$ & $\begin{array}{l}1,040 \\
1,087\end{array}$ & 2,964 & $0,003 *$ \\
\hline \multicolumn{7}{|c|}{ Sürekli İlgilenim Faktörlerine İlişkin Sonuçlar } \\
\hline Kişisel Zevk & $\begin{array}{l}\text { Kadın } \\
\text { Erkek }\end{array}$ & $\begin{array}{l}122 \\
329\end{array}$ & $\begin{array}{l}4,576 \\
4,465\end{array}$ & $\begin{array}{l}0,661 \\
0,612\end{array}$ & 1,680 & 0,094 \\
\hline Sosyal Bağlanma & $\begin{array}{l}\text { Kadın } \\
\text { Erkek }\end{array}$ & $\begin{array}{l}122 \\
329 \\
\end{array}$ & $\begin{array}{l}3,502 \\
3,569 \\
\end{array}$ & $\begin{array}{l}0,926 \\
0,889 \\
\end{array}$ & $-0,712$ & 0,477 \\
\hline Kendini İfade Etme & $\begin{array}{l}\text { Kadın } \\
\text { Erkek }\end{array}$ & $\begin{array}{l}122 \\
329 \\
\end{array}$ & $\begin{array}{l}4,251 \\
4,079 \\
\end{array}$ & $\begin{array}{l}0,776 \\
0,815 \\
\end{array}$ & 2,018 & $0,044 *$ \\
\hline
\end{tabular}




\begin{tabular}{|c|c|c|c|c|c|c|}
\hline \multicolumn{2}{|c|}{ Deneyim Düzeyi } & $\mathrm{N}$ & Ortalama & $\mathrm{SS}$ & $\mathrm{T}$ & $\mathrm{P}$ \\
\hline \multicolumn{7}{|c|}{ Motivasyon Faktörlerine İlişkin Sonuçlar } \\
\hline Rahatlama/Kaçış & $\begin{array}{c}\text { Orta } \\
\text { Düzey } \\
\text { Üst Düzey }\end{array}$ & $\begin{array}{l}222 \\
206\end{array}$ & $\begin{array}{l}4,558 \\
4,571\end{array}$ & $\begin{array}{l}0,632 \\
0,704\end{array}$ & $-0,195$ & 0,845 \\
\hline Yetkinlik & $\begin{array}{c}\text { Orta } \\
\text { Düzey } \\
\text { Üst Düzey }\end{array}$ & $\begin{array}{l}222 \\
206\end{array}$ & $\begin{array}{l}4,231 \\
4,155\end{array}$ & $\begin{array}{l}0,740 \\
0,941\end{array}$ & 0,922 & 0,357 \\
\hline Sosyalleşme & $\begin{array}{c}\text { Orta } \\
\text { Düzey } \\
\text { Üst Düzey }\end{array}$ & $\begin{array}{l}222 \\
206\end{array}$ & $\begin{array}{l}3,749 \\
3,768\end{array}$ & $\begin{array}{l}0,938 \\
0,945\end{array}$ & $-0,212$ & 0,832 \\
\hline Macera Deneyimi & $\begin{array}{c}\text { Orta } \\
\text { Düzey } \\
\text { Üst Düzey }\end{array}$ & $\begin{array}{l}222 \\
206\end{array}$ & $\begin{array}{l}3,587 \\
3,784\end{array}$ & $\begin{array}{l}1,150 \\
1,170\end{array}$ & $-1,748$ & 0,081 \\
\hline Meydan Okuma & $\begin{array}{c}\text { Orta } \\
\text { Düzey } \\
\text { Üst Düzey }\end{array}$ & $\begin{array}{l}222 \\
206\end{array}$ & $\begin{array}{l}3,818 \\
3,771\end{array}$ & $\begin{array}{l}1,060 \\
1,109\end{array}$ & 0,443 & 0,658 \\
\hline \multicolumn{7}{|c|}{ Sürekli İlgilenim Faktörlerine İlişkin Sonuçlar } \\
\hline Kişisel Zevk & $\begin{array}{c}\text { Orta } \\
\text { Düzey } \\
\text { Üst Düzey }\end{array}$ & $\begin{array}{l}222 \\
206\end{array}$ & $\begin{array}{l}4,427 \\
4,592\end{array}$ & $\begin{array}{l}0,661 \\
0,550\end{array}$ & $-2,801$ & $0,005 *$ \\
\hline Sosyal Bağlanma & $\begin{array}{c}\text { Orta } \\
\text { Düzey } \\
\text { Üst Düzey }\end{array}$ & $\begin{array}{l}222 \\
206\end{array}$ & $\begin{array}{l}3,436 \\
3,764\end{array}$ & $\begin{array}{l}0,859 \\
0,884\end{array}$ & $-3,885$ & $0,000 *$ \\
\hline Kendini İfade Etme & $\begin{array}{c}\text { Orta } \\
\text { Düzey } \\
\text { Üst Düzey }\end{array}$ & $\begin{array}{l}222 \\
206\end{array}$ & $\begin{array}{l}4,076 \\
4,226\end{array}$ & $\begin{array}{l}0,809 \\
0,793\end{array}$ & $-1,933$ & 0,054 \\
\hline
\end{tabular}

$(*): \mathrm{p}<0,05$

Tablo 3 incelendiğinde motivasyon boyutlarından "yetkinlik ve meydan okuma" ile sürekli ilgilenim boyutlarından "kendini ifade etme" katılımcıların cinsiyetlerine göre farklılık göstermiştir. Ortalamalar incelendiğinde kadın katılımcıların erkeklere göre daha yüksek motivasyona sahip oldukları ve ilgilenim düzeylerinin daha gelişmiş olduğu saptanmıştır. Deneyim düzeyine göre yapılan analiz sonuçlarına göre ise motivasyon boyutlarında katılımcıların deneyim düzeyleri ile farklılık gösteren herhangi bir faktör tespit edilmemiştir. Sürekli ilgilenim boyutlarından ise "kişisel zevk ve sosyal bağlanma" faktörlerinde farklılıklar tespit edilmiştir. Ortalamalar incelendiğinde üst düzey deneyime sahip bireylerin orta düzey deneyime sahip bireylere oranla daha yüksek ilgilenime sahip oldukları saptanmıştır.

Katılımcıların eğitim durumları ve deneyim süreleri ile motivasyonları ve sürekli ilgilenimleri arasında anlamlı bir fark olup olmadığı tek yönlü varyans analizi (One-Way ANOVA) ile belirlenmiş ve elde edilen bulgular Tablo 4'te sunulmuştur. 
Tablo 4. Motivasyon ve Sürekli İlgilenim Düzeylerinin Eğitim Düzeyi ve Deneyim Süresine Göre Farklılı̆̆

\begin{tabular}{|c|c|c|c|c|c|c|}
\hline \multicolumn{2}{|c|}{ Ĕ̈itim Düzeyi } & $\mathrm{N}$ & Ortalama & SS & $\mathrm{T}$ & $\mathrm{P}$ \\
\hline \multicolumn{7}{|c|}{ Motivasyon Faktörlerine İlişkin Sonuçlar } \\
\hline Rahatlama/Kaçış & $\begin{array}{l}\text { Lise } \\
\text { Üniversite } \\
\text { Lisansüstü } \\
\end{array}$ & $\begin{array}{c}116 \\
253 \\
65 \\
\end{array}$ & $\begin{array}{l}4,612 \\
4,548 \\
4,389 \\
\end{array}$ & $\begin{array}{l}0,678 \\
0,650 \\
0,734 \\
\end{array}$ & 2,315 & 0,100 \\
\hline Yetkinlik & $\begin{array}{l}\text { Lise } \\
\text { Üniversite } \\
\text { Lisansüstü }\end{array}$ & $\begin{array}{c}116 \\
253 \\
65 \\
\end{array}$ & $\begin{array}{l}4,278 \\
4,129 \\
4,184 \\
\end{array}$ & $\begin{array}{l}0,899 \\
0,832 \\
0,736 \\
\end{array}$ & 1,271 & 0,281 \\
\hline Sosyalleşme & $\begin{array}{l}\text { Lise } \\
\text { Üniversite } \\
\text { Lisansüstü } \\
\end{array}$ & $\begin{array}{c}116 \\
253 \\
65 \\
\end{array}$ & $\begin{array}{l}3,951 \\
3,644 \\
3,584 \\
\end{array}$ & $\begin{array}{l}0,884 \\
0,950 \\
0,907 \\
\end{array}$ & 5,143 & $0,006 *$ \\
\hline Macera Deneyimi & $\begin{array}{l}\text { Lise } \\
\text { Üniversite } \\
\text { Lisansüstü } \\
\end{array}$ & $\begin{array}{c}116 \\
253 \\
65 \\
\end{array}$ & $\begin{array}{l}3,797 \\
3,575 \\
3,630 \\
\end{array}$ & $\begin{array}{l}1,130 \\
1,165 \\
1,176 \\
\end{array}$ & 1,471 & 0,231 \\
\hline Meydan Okuma & $\begin{array}{l}\text { Lise } \\
\text { Üniversite } \\
\text { Lisansüstü } \\
\end{array}$ & $\begin{array}{c}116 \\
253 \\
65 \\
\end{array}$ & $\begin{array}{l}3,879 \\
3,697 \\
3,820 \\
\end{array}$ & $\begin{array}{l}1,190 \\
1,081 \\
0,907 \\
\end{array}$ & 1,218 & 0,297 \\
\hline \multicolumn{7}{|c|}{ Sürekli İlgilenim Faktörlerine İlişkin Sonuçlar } \\
\hline Kişisel Zevk & $\begin{array}{l}\text { Lise } \\
\text { Üniversite } \\
\text { Lisansüstü } \\
\end{array}$ & $\begin{array}{c}116 \\
253 \\
65 \\
\end{array}$ & $\begin{array}{l}4,580 \\
4,466 \\
4,405 \\
\end{array}$ & $\begin{array}{l}0,573 \\
0,652 \\
0,622 \\
\end{array}$ & 1,975 & 0,140 \\
\hline Sosyal Bağlanma & $\begin{array}{l}\text { Lise } \\
\text { Üniversite } \\
\text { Lisansüstü } \\
\end{array}$ & $\begin{array}{c}116 \\
253 \\
65 \\
\end{array}$ & $\begin{array}{l}3,722 \\
3,453 \\
3,511 \\
\end{array}$ & $\begin{array}{l}0,912 \\
0,858 \\
0,958 \\
\end{array}$ & 3,653 & $0,027 *$ \\
\hline Kendini İfade Etme & $\begin{array}{l}\text { Lise } \\
\text { Üniversite } \\
\text { Lisansüstü } \\
\end{array}$ & $\begin{array}{c}116 \\
253 \\
65 \\
\end{array}$ & $\begin{array}{l}4,198 \\
4,113 \\
4,005 \\
\end{array}$ & $\begin{array}{l}0,822 \\
0,785 \\
0,819 \\
\end{array}$ & 1,233 & 0,293 \\
\hline \multicolumn{2}{|c|}{ Deneyim Süresi } & $\mathrm{N}$ & Ortalama & SS & $\mathrm{F}$ & $\mathrm{P}$ \\
\hline \multicolumn{7}{|c|}{ Motivasyon Faktörlerine İlişkin Sonuçlar } \\
\hline Rahatlama/Kaçış & $\begin{array}{l}\text { 1-5 Y1l Aras1 } \\
6-10 \text { Y1l Aras1 } \\
11 \text { Y1l ve Üstü }\end{array}$ & $\begin{array}{l}122 \\
111 \\
162 \\
\end{array}$ & $\begin{array}{l}4,557 \\
4,594 \\
4,594 \\
\end{array}$ & $\begin{array}{l}0,605 \\
0,680 \\
0,658 \\
\end{array}$ & 0,139 & 0,870 \\
\hline Yetkinlik & $\begin{array}{l}\text { 1-5 Y1l Aras1 } \\
\text { 6-10 Y1l Aras1 } \\
11 \text { Y1l ve Üstü }\end{array}$ & $\begin{array}{l}122 \\
111 \\
162 \\
\end{array}$ & $\begin{array}{l}4,325 \\
4,108 \\
4,144 \\
\end{array}$ & $\begin{array}{l}0,742 \\
0,890 \\
0,867 \\
\end{array}$ & 2,362 & 0,096 \\
\hline Sosyalleşme & $\begin{array}{l}\text { 1-5 Y1l Aras1 } \\
6-10 \text { Y1l Aras1 } \\
11 \text { Y1l ve Üstü }\end{array}$ & $\begin{array}{l}122 \\
111 \\
162 \\
\end{array}$ & $\begin{array}{l}3,745 \\
3,837 \\
3,724 \\
\end{array}$ & $\begin{array}{l}0,825 \\
0,962 \\
0,988 \\
\end{array}$ & 0,516 & 0,597 \\
\hline Macera Deneyimi & $\begin{array}{l}\text { 1-5 Y1l Aras1 } \\
\text { 6-10 Y1l Aras1 } \\
11 \text { Y1l ve Üstü }\end{array}$ & $\begin{array}{l}122 \\
111 \\
162 \\
\end{array}$ & $\begin{array}{l}3,815 \\
3,612 \\
3,567 \\
\end{array}$ & $\begin{array}{l}1,054 \\
1,178 \\
1,211 \\
\end{array}$ & 1,711 & 0,182 \\
\hline Meydan Okuma & $\begin{array}{l}\text { 1-5 Y1l Aras1 } \\
\text { 6-10 Y1l Aras1 } \\
11 \text { Y1l ve Üstü }\end{array}$ & $\begin{array}{l}122 \\
111 \\
162 \\
\end{array}$ & $\begin{array}{l}3,855 \\
3,795 \\
3,759 \\
\end{array}$ & $\begin{array}{l}1,039 \\
1,090 \\
1,112 \\
\end{array}$ & 0,273 & 0,761 \\
\hline \multicolumn{7}{|c|}{ Sürekli İlgilenim Faktörlerine İlişkin Sonuçlar } \\
\hline Kişisel Zevk & $\begin{array}{l}\text { 1-5 Y11 Aras1 } \\
6-10 \text { Y1l Aras1 } \\
11 \text { Y1l ve Üstü }\end{array}$ & $\begin{array}{l}122 \\
111 \\
162 \\
\end{array}$ & $\begin{array}{l}4,467 \\
4,525 \\
4,535 \\
\end{array}$ & $\begin{array}{l}0,626 \\
0,549 \\
0,636 \\
\end{array}$ & 0,471 & 0,625 \\
\hline Sosyal Bağlanma & $\begin{array}{l}\text { 1-5 Y1l Aras1 } \\
\text { 6-10 Y1l Aras1 } \\
11 \text { Y1l ve Üstü }\end{array}$ & $\begin{array}{l}122 \\
111 \\
162 \\
\end{array}$ & $\begin{array}{l}3,405 \\
3,707 \\
3,659 \\
\end{array}$ & $\begin{array}{l}0,815 \\
0,858 \\
0,957 \\
\end{array}$ & 4,075 & $0,018 *$ \\
\hline Kendini İfade Etme & $\begin{array}{l}\text { 1-5 Y1l Aras1 } \\
6-10 \text { Y1l Aras1 } \\
11 \text { Y1l ve Üstü }\end{array}$ & $\begin{array}{l}122 \\
111 \\
162 \\
\end{array}$ & $\begin{array}{l}4,038 \\
4,225 \\
4,177 \\
\end{array}$ & $\begin{array}{l}0,817 \\
0,825 \\
0,765 \\
\end{array}$ & 1,777 & 0,171 \\
\hline
\end{tabular}


ANOVA testlerinde gözlem sayılarının otuza yakın olması gerekmektedir (Alpar 2010: 159). Bu kapsamda gözlem sayıları 30'dan düşük olan ilkokul ve ortaokul eğitim düzeyine sahip bireyler analize dâhil edilmemiştir. Ayrıca deneyim süresi gözlem sayıları arasındaki farklı1ık sebebiyle "düzenli bisiklet sürmüyorum $(n=20)$ ve 5 yıldan az $(n=36)$ " grupları dâhil edilmemiştir. Analizler neticesinde lise düzeyindeki bireylerin diğer gruplara nazaran daha yüksek motivasyona ve sürekli ilgilenim düzeyine sahip oldukları tespit edilmiştir. Ayrıca deneyim süresi arttıkça bireylerin bisiklet etkinliklerine "sosyal bağlanma" düzeyinde daha fazla katılım sağladıkları söylenebilmektedir.

Çalışma kapsamında etkinliklere katılan bireylerin motivasyonları ve sürekli ilgilenim düzeyleri arasındaki ilişkiyi açıklamaya yönelik çoklu regresyon analizinden faydalanılmıştır. Elde edilen bulgular Tablo 5'te sunulmuştur.

Tablo 5. Çoklu Regresyon Analizi Sonuçları

\begin{tabular}{|l|c|c|c|c|c|}
\hline & \multicolumn{2}{|c|}{$\begin{array}{c}\text { Standartlaştırılmamış } \\
\text { Katsayılar }\end{array}$} & $\begin{array}{c}\text { Standartlaştırılmı̧ } \\
\text { Katsayılar }\end{array}$ & T Değeri & Anlamlılık (p) \\
\hline & B & Standart Hata & Beta & & 0,000 \\
\hline Sabit & 2,591 & 0,195 & & 13,308 & $0,000^{*}$ \\
\hline Rahatlama / Kaçış & 0,240 & 0,047 & 0,255 & 5,115 & 0,233 \\
\hline Yetkinlik & 0,050 & 0,041 & 0,066 & 1,195 & 0,266 \\
\hline Sosyalleşme & 0,039 & 0,035 & 0,058 & 1,113 & 0,394 \\
\hline Macera Deneyimi & 0,023 & 0,027 & 0,042 & 0,853 & $0,004^{*}$ \\
\hline Meydan Okuma & 0,099 & 0,034 & 0,171 & 2,927 & \\
\hline
\end{tabular}

(Bağımlı Değişken: Kişisel Zevk)

\begin{tabular}{|l|l|l|l|l|l|}
\hline Sabit & 1,054 & 0,267 & & 3,942 & 0,000 \\
\hline Rahatlama / Kaçış & 0,074 & 0,064 & 0,055 & 1,152 & 0,250 \\
\hline Yetkinlik & 0,083 & 0,057 & 0,077 & 1,462 & 0,144 \\
\hline Sosyalleşme & 0,235 & 0,048 & 0,245 & 4,874 & $0,000^{*}$ \\
\hline Macera Deneyimi & 0,115 & 0,037 & 0,148 & 3,135 & $0,002^{*}$ \\
\hline Meydan Okuma & 0,136 & 0,046 & 0,164 & 2,933 & $0,004^{*}$ \\
\hline
\end{tabular}

(Bağımlı Değişken: Sosyal Bağlanma)

\begin{tabular}{|l|l|l|l|l|c|}
\hline Sabit & 1,078 & 0,229 & & 4,703 & 0,000 \\
\hline Rahatlama / Kaçış & 0,361 & 0,055 & 0,297 & 6,535 & $0,000^{*}$ \\
\hline Yetkinlik & 0,101 & 0,049 & 0,104 & 2,069 & $0,039^{*}$ \\
\hline Sosyalleşme & 0,065 & 0,041 & 0,076 & 1,579 & 0,115 \\
\hline Macera Deneyimi & 0,014 & 0,031 & 0,020 & 0,438 & 0,662 \\
\hline Meydan Okuma & 0,181 & 0,040 & 0,243 & 4,559 & $0,000^{*}$ \\
\hline
\end{tabular}

(Bağımlı Değişken: Kendini İfade Etme)

Yukarıdaki tablo incelendiğinde elde edilen bulgular şunlardır;

- Bisiklet etkinliklerine katılan bireylerin "kişisel zevk" düzeyinde sürekli ilgi göstermelerinde "rahatlama/kaçış ve meydan okuma" güdüleri etkilidir,

- Bireylerin etkinliklere sürekli ilgi göstermeleri sonucu etkinliklere sosyal açıdan bağlanmalarında "sosyalleşme, macera deneyimi ve meydan okuma" güdüleri etkilidir,

- Bireylerin bisiklet etkinlikleri aracılığıyla kendilerini ifade etmelerinde "rahatlama/kaçış, meydan okuma ve yetkinlik” güdüleri etkilidir. 
Genel bir değerlendirme yapılacak olursa; en önemli motivasyon boyutu "meydan okuma" olarak tespit edilmiştir. Bunun nedeni ise bu faktör sürekli ilgilenim boyutlarının tamamını diğer bir deyişle bağımlı değişkenlerin hepsini etkilemektedir. "Yetkinlik, sosyallik ve macera deneyimi” faktörleri ise bağımlı değişkenlerden sadece birer tanesine etki edebilmektedir.

\section{Sonuç ve Öneriler}

Motivasyon kavramı, turizm çalışmaları başladığı tarihten itibaren araştırmacıların odak noktası olmuştur (Çetinsöz ve Artuğer 2014, 573). Turistlerin karar verme süreçlerini anlamada en önemli nokta, motivasyonlarının belirlenmesi ve öncelik verilmesidir (Crompton ve McKay 1997, 426). Ek olarak katılımcıların sürekli ilgilenim düzeylerini ölçmek boş zaman, spor ve turizm tüketicilerinin motivasyonlarını anlamada yardımcı olabilmektedir (Ritchie ve diğerleri 2010, 412).

Son yıllarda destinasyonlar, turizm teklifleri geliştirmek ve destinasyonlar arası rekabette söz sahibi olabilmek amaciyla bisiklet etkinliklerinden faydalanmak istemektedir (Gazzola ve diğerleri 2018, 1). Yapılan etkinlikler aracılığıyla birçok ziyaretçinin bir destinasyona seyahat etmesi teşvik edilmekte, ziyaret edilen destinasyonların katılımcılar aracılığıyla başkalarına tavsiye edilmesi sağlanmaktadır. Bu sayede şehirler, bölgeler hatta ülkeler bisiklet etkinliklerini mevcut kalkınma stratejileri arasına eklemektedirler (Çelik Uğuz ve Özbek 2018, 88).

İzmir'de gerçekleştirilen mevcut çalışmada bisiklet etkinliklerine katılan bireylerin motivasyonları önem sırasına göre "Rahatlama/Kaçış, Yetkinlik, Sosyalleşme, Macera Deneyimi ve Meydan Okuma” şeklinde tespit edilmiştir. Sürekli ilgilenim düzeyleri ise önem sırasına göre "Kişisel Zevk, Sosyal Bağlanma ve Kendini İfade Etme” şeklinde saptanmıştır. Elde edilen veriler Ritchie ve diğerlerinin (2010) çalışmasıyla farklılık göstermiştir. Hofstede'nin Kültürel Boyutları Kuramı'na göre ülkeler karşılaştırıldığında Türkiye "güç mesafesi" boyutunda 66 puan alırken Avustralya 38 puan almaktadır. Yüksek puana sahip ülkelerde bireyler eğitim, statü ve gelir bakımından eşit dağılım göstermemektedirler. Bisiklet etkinliklerine katılan bireylerde oluşan bu farklılıklar motivasyonları da etkilemektedir. Ayrıca Avustralya "bireycilik" boyutunda doksan puan alırken Türkiye otuz yedi puan almaktadır. Bireycilik boyutunun temel mantığı bir toplumun üyeleri arasında sürdürdüğü karşılıklı bağımlılık derecesidir (Hofstede-insights 2020). İzmir'de yapılan bu çalışmada Ritchie ve diğerlerinden (2010) farklı olarak "sosyal bağlanma" faktörünün elde edilmesi bu kültürel boyutla ilişkilendirilebilmektedir. Ek olarak Avustralya'da kullanılan orijinal ölçek konaklamalı bisiklet turlarına katılan bisiklet turistleriyle yapılmıştır. İzmir'de yapılan bu 
çalışmada ise yarım gün veya tam günlük bisiklet etkinliklerine katılan bireyler ile yapılmıştır. $\mathrm{Bu}$ durum elde edilen bulgular arasındaki farklılığın nedenlerinden bir diğeri de olabilmektedir.

Yapılan tüm analizlerin ortak bir sonucu olarak bireylerin etkinliklere katılımlarını etkileyen motivasyon unsurlarının ve bu etkinliklere duydukları ilgi düzeylerinin saptanması, incelenmesi, aralarındaki ilişkinin irdelenmesi ve sonuçların göz önünde bulundurularak bu turizm çeşidinin geliştirilmesine yönelik yeni kararlar alınması ve uygulanması İzmir destinasyonun bu turizm çeşidi bakımından gelişimine ve ülkenin turizm potansiyeline olumlu etki edecektir. Bisiklet etkinlikleri iyi bir şekilde planlanır ve yönetilirse destinasyonlara olumlu pek çok katkısı olacaktır. Bisiklet etkinliklerinin yaygınlaşması ve katılımın artması için yapılması gereken uygulamalara yönelik öneriler aşağıda sıralanmaktadır;

- Güvenlik endişesi duyan kadın kullanıcılara uygun eğitimler verilmeli ve bisiklet kullanımına teşvik edilmelidir.

- Elektrikli bisiklet üretimine destek vererek yaşlı bireylerin etkinliklere katılımları sağlanmalıdır.

- Deneyim düzeyi düşük bireylere eğitimler verilmeli, kask kullanımı özendirilmelidir.

- Yeni rotalar oluşturulmalı, var olan bisiklet yollarının sürekli bakımları yapılmalıdır.

- Ulaşım araçları ile bisikletler entegre edilmeli, bisiklet park yerleri kurulmalı ve elektronik bisikletler için şarj dolum stantları sağlanmalıdır.

- Belediyelerce desteklenen yeni mobil uygulamalar geliştirilmeli ve bisiklete ilgi duyanlara yönelik tüm bilgiler bu uygulamalar ile sağlanmalıdır.

- Turistik faaliyetlerin yoğun olduğu bölgelere bağlanan yeni rotalar geliştirilmeli, güzergah boyunca bisikletlilerin her türlü ihtiyacına cevap verecek mekânların açılmasına destek verilmelidir.

- Motorlu taşıtlar ile yapılan seyahatlerin azaltılmasına yönelik çalışmalar yapılarak hava kirliliği ve gereksiz enerji kullanımının önüne geçilmelidir.

- Bisiklet kullanımının sağlığa olan faydaları bireylere anlatılmalı ve daha yaşanılabilir bir kent, temiz bir hava için bisiklet kullanımı teşvik edilmelidir.

Yapılan çalışmada Türkiye'de ilk defa bisiklet etkinliklerine katılan bireylerin sürekli ilgilenim düzeyleri incelenmiştir. Araştırma İzmir'de bisiklet etkinliklerine katılan bireyler ile yapılmıştır. Daha sonraki çalışmalarda Türkiye'nin farklı bölgelerinde ve daha geniş kitleler ile yapılması bisiklet turizminin geliştirilmesine ve bu faaliyeti oluşturma girişimlerine faydalı olacaktır. Ayrıca araştırma sadece Türk katılımcılar ile yapılmıştır. Daha sonraki çalışmalarda 
Sağlam, M. C., Kömürcü, S. / Journal of Yasar University, 2021, 16/63, 1355-1372

destinasyonları bisiklet etkinlikleri aracılığıyla ziyaret eden yabancı katılımcılar ile yapılacak çalışmaların da turizm alanyazınına olumlu katkılar sağlayacağı düşünülmektedir. 


\section{KAYNAKÇA}

Akkoç, İ. 2015. “Tüplü Dalış Turizmine Katılan Turistlerin Güdüleri ve İlgilenimleri: Türkiye Üzerine Bir Araştırma". Yüksek Lisans Tezi. Eskişehir: Anadolu Üniversitesi Sosyal Bilimler Enstitüsü.

Alpar, R. 2010. Spor Sağlık ve Ĕgitim Bilimlerinden Örneklerle Uygulamall İstatistik ve Geçerlik Güvenirlik. Ankara: Detay Yayınc1lik.

Ardahan, F. ve Mert, M. 2014. "Bireyleri Bisiklet Kullanmaya Motive Eden Faktörler Ölçeğinin Geliştirilmesi ve Türk Popülasyonu İçin Güvenirlilik Geçerlilik Çalışması”. Akademik Sosyal Araştırmalar Dergisi, 2(1): 409-427.

Bayrakçı, S. 2014. "Yerel Yemek Tüketim Motivasyonlarının Turistlerin Tekrar Ziyaret Niyetlerine Etkisi: Gaziantep'i Ziyaret Eden Yerli Turistler Üzerine Bir Araştırma”. Yüksek Lisans Tezi. Mersin: Mersin Üniversitesi Sosyal Bilimler Enstitüsü.

Başol, G. 2008. “Bilimsel Araştırma Süreci ve Yöntem.” Bilimsel Araştırma Yöntemleri içinde, Kılıç, O. Cinoğlu, M. (Editörler), 113-143. İstanbul: Lisans Yayıncilik.

Beard, J. ve Ragheb, M. (1983). “Measuring Leisure Motivation”. Journal of Leisure Research, 15(3): 219-228.

Can, E. 2015. “Boş Zaman, Rekreasyon ve Etkinlik Turizmi İlişkisi”. İstanbul Sosyal Bilimler Dergisi, 10: 1-17.

Chang, H.-M. ve Huang, Y.-T. 2012. "Paragliding Adventure Recreation Consumers' Activity Motivation, Enduring Involvement and Their Involved Behavior". The Journal of International Management Studies, 7(2): 61-74.

Crompton, J. 1979. "Motivation For Pleasure Vacation”. Annals of Tourism Research, 6(4): 408-424.

Crompton, J. L. ve McKay, S. L. 1997. "Motives of Visitors Attending Festival Events". Annals of Tourism Research, 24(2): 425-439.

Çelik Uğuz, S. ve Özbek, V. 2018. "Destinasyon Sadakatini Etkileyen Faktörler: Bisiklet Turizmi ve Burhaniye Bisiklet Festivali Örneği”. International Review of Economics and Management, 6(2): 84-102.

Çetinsöz, B. ve Artuğer, S. 2014. "Yabancı Turistlerin Antalya'yı Tercih Etmesinde Etkili Olan Çekici Faktörlerin Belirlenmesine Yönelik Bir Çalışma”. The Journal of International Social Research, 7(32): 573-582.

Dann, G. 1977. “Anomie, Ego-enhancement and Tourism”. Annals of Tourism Research, 4(4): 184-194.

Etikan, I., Musa, S. A. ve Alkassim, R. S. 2016. "Comparison of Convenience Sampling and Purposive Sampling”. American Journal of Theoretical and Applied Statistics. 5(1): 1-4.

Fodness, D. 1994. "Measuring Tourist Motivation”. Annals of Tourism Research, 21(3): 555-581.

Francis, C. 2003. "Tourism Overview”. Tourism Management in Southern Africa içinde, B. Lubbe (Editör), 1-29. Cape Town: Maskew Miller Longman.

Gazzola, P., Pavione, E., Grechi, D. ve Ossola, P. 2018. "Cycle Tourism as a Driver for the Sustainable Development of Little-Known or Remote Territories: The Experience of the Apennine Regions of Northern Italy”. Sustainability, 10: 1-19.

Gürbüz, B., Çimen, Z. ve Aydın, İ. 2018. "Serbest Zaman İlgilenim Ölçeği: Türkçe Formu Geçerlik ve Güvenirlik Çalışması”. SPORMETRE Beden Ĕ̆itimi ve Spor Bilimleri Dergisi, 16(4): 256-265

Havitz, M. ve Howard, D. 1995. "How Enduring Is Enduring Involvement? A Seasonal Examination of Three Recreational Activities". Journal of Consumer Psychology, 4(3): 255-276.

Havitz, M. ve Dimanche, F. 1997. "Leisure Involvement Revisited: Conceptual Conundrums and Measurement Advances". Journal of Leisure Research, 29: 245-278.

Hofstede-insights. 2020. https://www.hofstede-insights.com/country-comparison/australia, turkey/ Erişim Tarihi: 01.07.2020

Huang, S. ve Hsu, C. 2009. "Travel Motivation: Linking Theory to Practice”. International Journal of Culture, Tourism and Hospitality Research, 3(4): 287-295.

Iso-Ahola, S. 1982. "Toward A Social Psychological Theory of Tourism Motivation: A Rejoinder". Annals of Tourism Research, 9(2): 256-262.

Jago, L. K. ve Shaw, R. N. 1998. "Special Events: A Conceptual and Definitional Framework". Festival Management and Event Tourism, 5(1-2): 21-32.

Kim, K. 2008. "Analysis of Structural Equation Model for the Student Pleasure Travel Market: Motivation, Involvement, Satisfaction, and Destination Loyalty”. Journal of Travel \& Tourism Marketing, 24(4): 297 313.

Kim, K., Uysal, M. ve Chen, J. 2002. "Festival Visitor Motivation From The Organizer's Point of View". Event Management, 7(2): 127-134.

Kim, Y., Pearce, P., Morrison, A. ve O'Leary, J. 1996.” Mature vs. Youth Travelers: The Korean Market”. Asia Pacific Journal of Tourism Research, 1(1): 102-112.

Kouthouris, C. 2009. "An Examination of the Relationships between Motivation, Involvement and Intention to Continuing Participation among Recreational Skiers”. International Journal of Sport Management, Recreation \& Tourism, 4(a): 1-19. 
Kyle, G., Absher, J. ve Hammitt, W. 2005. "An Examination of the Motivation-Enduring Involvement Relationship". Proceedings of the 2005 northeastern recreation research symposium: 10-12 Nisan. 238246. Bolton Landing, NY: Miscellaneous Publication.

Kyle, G., Bricker, K., Graefe, A. ve Wickham, T. 2004. “An Examination of Recreationists' Relationships with Activities and Settings". Leisure Sciences, 26(2): 123-142.

Kyle, G., Absher, J., Hammitt, W. ve Cavin, J. 2006. "An Examination of the Motivation-Involvement Relationship”. Leisure Sciences, 28(5): 467-485.

Lee, C.-K., Lee, Y.-K. ve Wicks, B. 2004. "Segmentation of Festival Motivation by Nationality and Satisfaction". Tourism Management, 25(1): 61-70.

Manfredo, M., Driver, B. ve Tarrant, M. 1996. "Measuring Leisure Motivation: A Metaanalysis of the Recreation Experience Preference Scales". Journal of Leisure Research, 28(3): 188-213.

Maslow, A. 1970. Motivation and Personality. New York: Harper \& Row Publishers.

McIntyre, N. 1989. "The Personal Meaning of Participation: Enduring Involvement". Journal of Leisure Research, 21(2): 167-179.

O’Leary, S. ve Deegan, J. 2005. "Ireland's Image as a Tourism Destination in France: Attribute Importance and Performance". Journal of Travel Research, 43: 247-256.

Özdemir, M. 2015. “Türkiye'de Bisiklet Turizmi "Velosipet ile Bir Cevelan”. Anatolia: Turizm Araştırmaları Dergisi, 26(2): 320-327.

Park, K.-S., Reisinger, Y. ve Kang, H.-J. 2008. "Visitors' Motivation for Attending the South Beach Wine and Food Festival,Miami Beach, Florida". Journal of Travel \& Tourism Marketing, 25(2): 161-181.

Ritchie, B. 1998. "Bicycle Tourism in the South Island of New Zealand: Planning and Management Issues". Tourism Management, 19 (6): 567-582.

Ritchie, B. W. 2000. "Cycle Tourism in the South Island of New Zealand”. Doktora Tezi. New Zealand: University of Otago.

Ritchie, B., Tkaczynski, A. ve Faulks, P. 2010. "Understanding the Motivation and Travel Behavior of Cycle Tourists Using Involvement Profiles”. Journal of Travel \& Tourism Marketing, 27(4): 409-425.

Sarıbaş, Ö., Kömürcü, S. ve Akbaba, A. 2020. "The concept of Social Entrepreneurship in tourism: A Bibliometric Analysis for Tourism Literature". Eurosia Journal of Social Sicences and Humanities, 7(4), 50-59.

Schwartz, A. 2006. Motivation: Linking Performance to Goals. Waverley, MA: A.E. Schwartz \& Associate.

Simkova, E. ve Holzner, J. 2014. "Motivation of Tourism Participants". Procedia - Social and Behavioral Sciences, 159: 660-664.

Thapa, B., Confer, J. ve Mendelsohn, J. 2004. Trip Motivations Among Water-Based Recreationists. Parks and Tourism University of Florida: Center for Tourism Research \& Development Dept. of Recreation.

Uysal, M., Gahan, L. ve Martin, B. 1993. “An Examination of Event Motivations: A Case Study". Festival Management \& Event Tourism, 1(1): 5-10.

Uysal, M., Li, X. ve Sirakaya-Turk, E. 2008. "Push-Pull Dynamics in Travel Decisions". Handbook of Hospitality Marketing Management içinde, A. P. Haemoon Oh (Editör), 413-439. Burlington, MA,USA: Elsevier Ltd.

Venkatraman, M. 1989. "Involvement and Risk". Psychology and Marketing,6(3): 229-247.

Yılmaz, L. ve Güler, M. E. 2017. “Türkiye'de Muafazakâr Değerler Bağlamında Turizm ve Tatil Algısındaki Değişme”. International Journal of Contemporary Tourism Research, 1(1): 17-25.

Weigand, L. 2008. "A Review of Literature: The Economic Benefits of Bicycling". Initiative for Bicycle \& Pedestrian Innovation, 1-11.

Zaichkowsky, J. L. 1994. "Research Notes: The Personal Involvement Inventory: Reduction, Revision and Application to Advertising". Journal of Advertising, 23: 59-70. 